\author{
Monisha Ravi ${ }^{1}$, Balasubramanian Murugesan ${ }^{1 *}$, Arul Jeyakumar ${ }^{2}$, Kiranmayi Raparthi ${ }^{3}$ \\ ${ }^{1}$ Department of Civil Engineering, SRM IST, Kattankulathur, Chennai, India \\ ${ }^{2}$ Department of Mechanical Engineering, SRM IST, Kattankulathur, Chennai, India \\ ${ }^{3}$ School of Architecture and Planning, Anna University, Chennai, India \\ *balamv86@gamil.com
}

\title{
A REVIEW ON UTILIZING THE MARINE BIOREFINERY WASTE IN CONSTRUCTION RAW MATERIALS TO REDUCE LAND POLLUTION AND ENHANCE GREEN ENVIRONMENT
}

\begin{abstract}
This research mainly concentrates on eco-friendly construction material. Production of cement and concrete industries release huge amount of carbon dioxide $\left(\mathrm{CO}_{2}\right)$ and greenhouse gases which affect the environment and also there is a demand in construction material by man-made or nature. The construction sector finds an economic and eco-friendly cement replacement material to achieve the demand for green concrete that improve the energy conservation and better energy saving material. In marine Bio-refinery waste produce huge quantity of calcium carbonate, whose disposal is cause of major concern. Pre-eminent solution for this problem is utilizing the marine shell waste in cement and concrete. It revises the manufacturing process to reduce the raw material usage in production and adoptable material for global warming. Therefore, the researchers focus on marine waste sea shells as the replacement material in construction industry to save the energy and also give sustainable green material. As per the previous studies by the researchers to determine the chemical composition, specific gravity, water absorption, particle size distribution of seashells and also compressive, flexural and tensile strength of concrete. It shows the seashell is filler material that slightly increases the strength when compared to the conventional materials and therefore the sea shells are suitable for the construction field to manufacture the cement and concrete with eco-friendly manner.
\end{abstract}

Keywords: eco-friendly material; green environment; sustainable development in construction; mechanical properties; green material; waste management

\section{INTRODUCTION}

In construction sector, concrete is the main key material which is used for all purpose of the building $[1,2]$. From the production industries, it produces large number of global wastes every year, it causes global and public health issues [3, 4]. The construction industries are increasing every year, there is a problem of shortage of material. So, the researcher's interest in search of alternate building materials $[5,6]$. Recently the construction material production has been using natural aggregates, now a days research works are proposed to use natural aggregate as by product in concrete [1]. In preceding two or three decades the environmental consciousness about cement which has great volume of $\mathrm{CO}_{2}$ footprint [2]. World economy, 
the cement industry meets several challenges that are lack of raw materials, deficiency of fossil fuels and endless demand for construction. In cement manufacture process produce approximately $6-10 \%$ amount of $\mathrm{CO}_{2}$ released into the environment [7, 8]. The cement industry faces many challenges, including the depletion of natural raw material resources, the demand for cement production, the need to reduce energy consumption in the production of portland cement clinker, and environmental issues. The remaining emissions are generated by limestone firing. One $\mathrm{kg}$ of Portland cement clinker emits $0.87 \mathrm{~kg}$ of $\mathrm{CO}_{2}$ into the atmosphere. For these environmental issues, cement industries somewhere practising several by product materials such as industrial waste, blast furnace slag, agricultural waste, mining waste etc. Increased volume fractions of supplementary materials such as fly ash, slag and volcanic dust produce more environmentally sustainable concrete and a mixture with high workability, extreme strength and durability $[9,10]$. These by product act as a mineral admixture that reduce the environmental impact of cement production $[8,11]$. The scope of uses waste material which production of the material does not affect the environment. The cost of lime and ordinary Portland cement having large scale of greenhouse gas emission into the environment [11-13]. Due to the environmental issues, the main focus of the research is to identify the ecological material that produce minimum level of gas emission in production of cement [14]. The main problems focus on construction sector there is a demand on new resource of construction materials and also the several alternative materials act as low carbon producer, geo polymers, negative carbon cement and green cement etc. [15, 16]. Focusing of calcium carbonate material in cement can obtained from marine waste. In marine bio-refinery large part of shells were excessively produced and its disposed in land about 438 billion tons of shell waste every year introducing new process of manufacture of cement by reuse of sea shells as calcium carbonate. Fig. 1 shows the map of the countries produce of shells in sea $[17,18]$. In this aspects, it is a salient idea to use eco-friendly waste material as a by-product for manufacturing cement and concrete [1]. Tremendous volume of marine sea shell waste are generated and it was burning and burying every year of this marine waste are causes environmental and global issues [3]. Seashells waste is utilized as the alternative raw materials in the construction industry [19]. In previous research articles have been done by many authors, using sea shells as cementitious material and additive for cement by calcinations and milling process. Some of them are utilizing the shells are fine aggregate in concrete [4].

a) Map of the countries producers of Crassostrea gigas

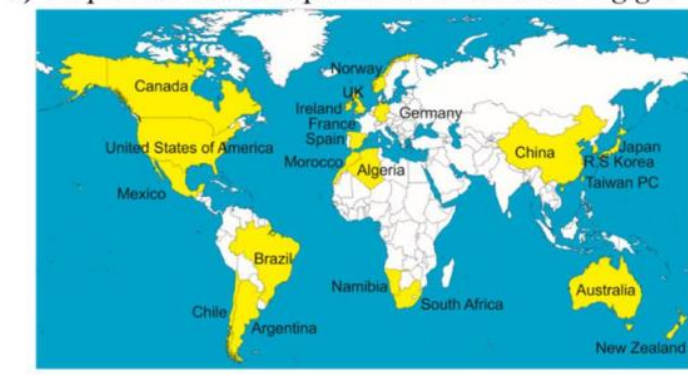

b) Global amount of Crassostrea gigas since the $1950 \mathrm{~s}$

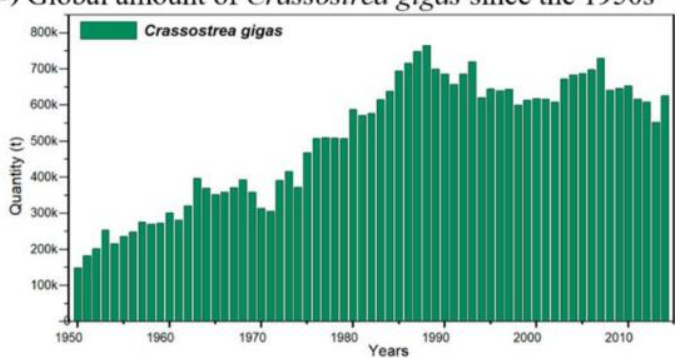

Fig. 1. Map of the countries produce of shells in sea [5]
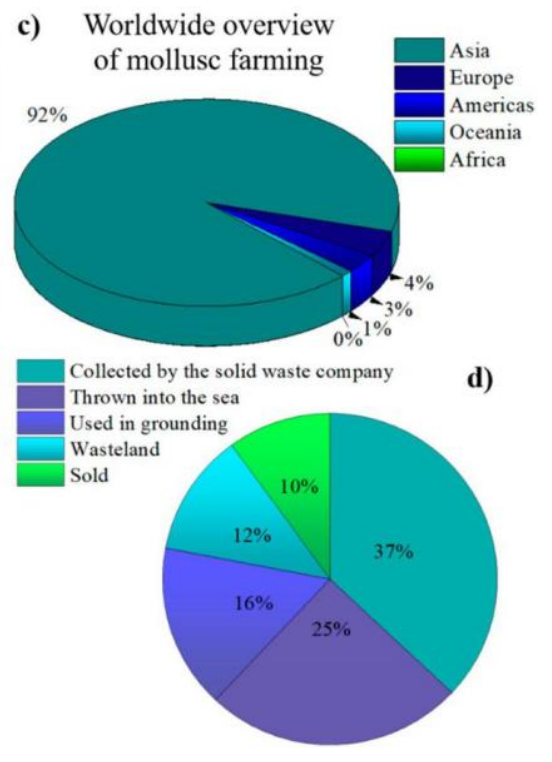
Utilizing oyster shell, mussel shell, clam shell, snail shell, cockle shell, Peruvian shell, queen scallop shell used as cement replacement and coarse aggregate replacement material and the coral reef as fine aggregate and coarse aggregate in the construction industry. Another by-product in marine as coral colony made up of millions of coral Sea polyps [20, 21]. Coral reef is formed by volcanic settlement in rock area, the reef is made up of $96 \%$ of calcite and aragonite [22]. For the potential use of construction material as coral reef to quarried $\rightarrow$ coral sand $\rightarrow$ coral gravel as fine aggregate, coarse aggregate, coral tiles, coral sand and coral cement $[10,23,24]$. coral reef aggregate is experimentally investigated, the physical properties of natural aggregate is comparatively higher than conventional concrete [25]. The major problem is to identify the low carbon material, and compared with a traditional filling. Sea shell materials have the advantages of easy distribution in complex sites, no settlement, strength, duration, flexibility, and the ability to combine with nontraditional materials. The results show that the mechanical properties and the physical properties containing $10-30 \%$ seashells are similar to the conventional materials. Therefore, this study simulated the feasibility of utilizing the waste seashells as a replacement material in cement and concrete raw materials to reduce $\mathrm{CO}_{2}$ emissions.

\section{MATERIALS AND METHODS}

\section{Ordinary Portland Cement}

In cement production the essential raw materials are lime stone $\left(\mathrm{CaCO}_{3}\right)$ and clay $\left(\mathrm{SiO}_{2}\right)$ [26]. These two materials comply under the calcination process [27, 28]. This calcination process under thermal treatment with adding minerals admixtures. From this calcination process cement clinkers are generated up to $1200-1500^{\circ} \mathrm{C}[16,29]$. The reaction is calcium carbonate + silica (heat) $\rightarrow$ calcium silicate (clinker) + carbon dioxide:

$$
3 \mathrm{CaCO}_{3}+\mathrm{SiO}_{2} \rightarrow \mathrm{Ca}_{3} \mathrm{SiO}_{5}+3 \mathrm{CO}_{2}
$$

The basic components of a modern Portland cement finished clinkers are tricalcium silicate $50 \%$ dicalcium silicate $25 \%$ tricalcium aluminate $10 \%$ tetra calcium aluminoferrite $10 \%$ and gypsum $5 \%$ [30-32].

\section{Oyster Shell}

The production rate of oyster shell waste is detailed about 119 metric tons per year for the previous two to five decades. Dumping of this shell waste creates environmental problems and health issues due to disposal in landfill [33]. Hence the research focus on utilized oyster shell waste and reuse as the potential cementitious material and also oyster shell act as the geo polymers material $[17,34]$. By using the waste oyster shell, it decreases the issues of waste management. The mechanism of oyster shell on cement in hydration process. The experimental investigation done for this shell waste gives high compressive strength, porosity and workability [7]. The manufacture process of calcium carbonate powder through calcination of oyster shell waste and the surface of oyster shell was brushed and soaked in water for a week or more to remove salt and other particles in shells. Oyster shell was washed naturally dried and then crushed $[35,36]$. Crushed oyster shell was calcined in an electric furnace at $1000^{\circ} \mathrm{C}$ for $3 \mathrm{hrs}$ and then it cooled down to room temperature in the 
electric furnace, and then pulverized to pass a $150-\mu \mathrm{m}$ sieve. Fig. 2 shows the manufacture process of oyster shell [8].
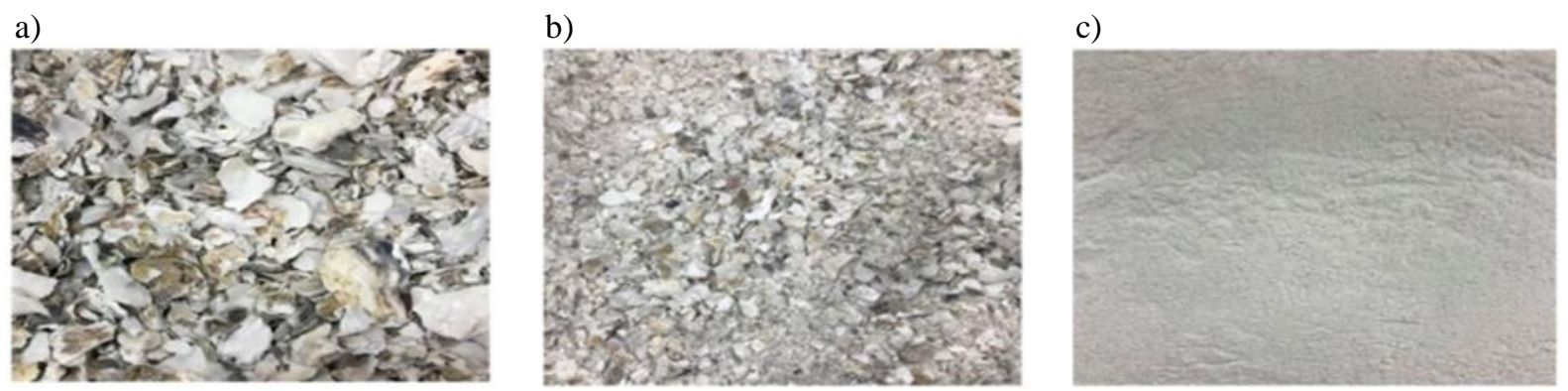

Fig. 2. (a) Surface of oyster shell, (b) Crushed oyster shell, (c) Powdered shell using electric furnace about $1000^{\circ} \mathrm{C}$

\section{Mussel Shell}

Marine mussel shells are utilized in this research. These shells are used as both fine aggregate and coarse aggregate. The shells are crushed and segregated from heat treatment $\rightarrow$ mussel shell gravel $\rightarrow$ crushing $\rightarrow$ coarse aggregate $\rightarrow$ sieving $\rightarrow$ fine aggregate $[3,37]$. The fraction of natural gravel particle size is similar to mussel shell gravel particle size about 4$16 \mathrm{~mm}$ in Fig. 3 and physical properties of mussel shell is given in Table 1.

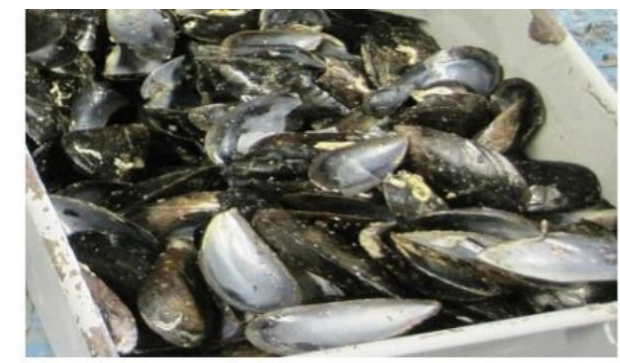

Shell (withouttreatment) large: $76 \mathrm{mmwide}: 37 \mathrm{~mm}$

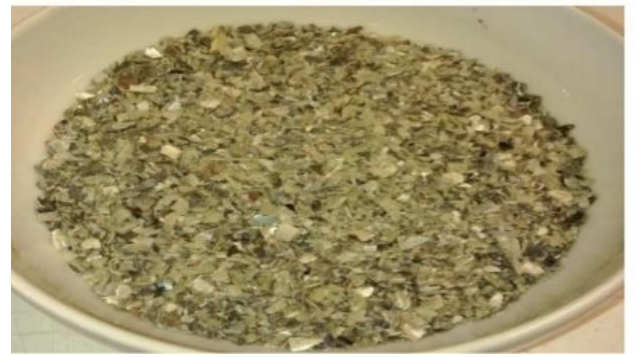

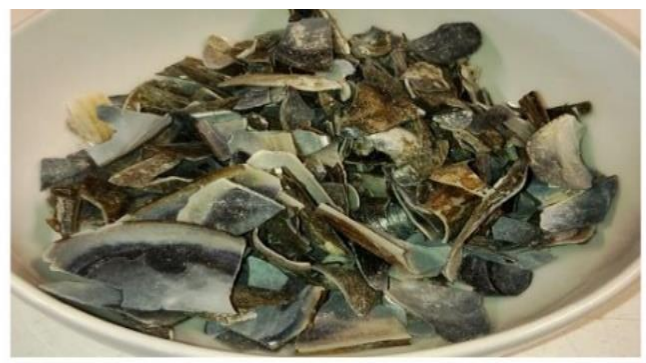

Mussel Shell gravel, MG (heattreatment)

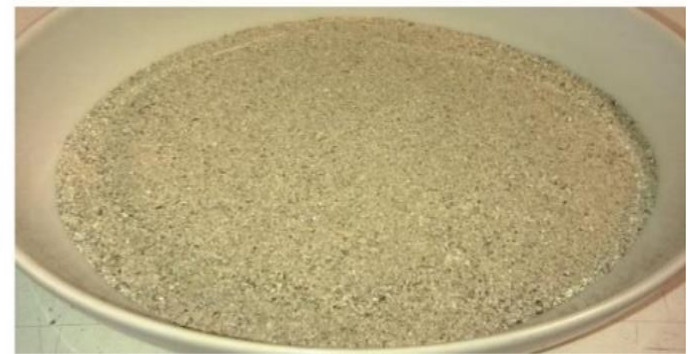

Fig. 3. Manufacture of mussel shell [11]

\section{Peruvian Scallop Shell}

Peruvian scallop is the marine waste Fig. 4 shows the features of shell. The shells are curved shape with hard flat up to $2-3 \mathrm{~mm}$ thickness joined with hinged ligaments. The Peruvian shells are treated by manual process washing $\rightarrow$ dried $\rightarrow$ crushed by hammer $\rightarrow$ sieved up to $4.75 \mathrm{~mm}-1.19 \mathrm{~mm}$ after the cleaning process of shells [38], Physical and chemical properties are calculated in Table 1. After testing the samples of crushed shell waste is similar to natural aggregate [12]. 

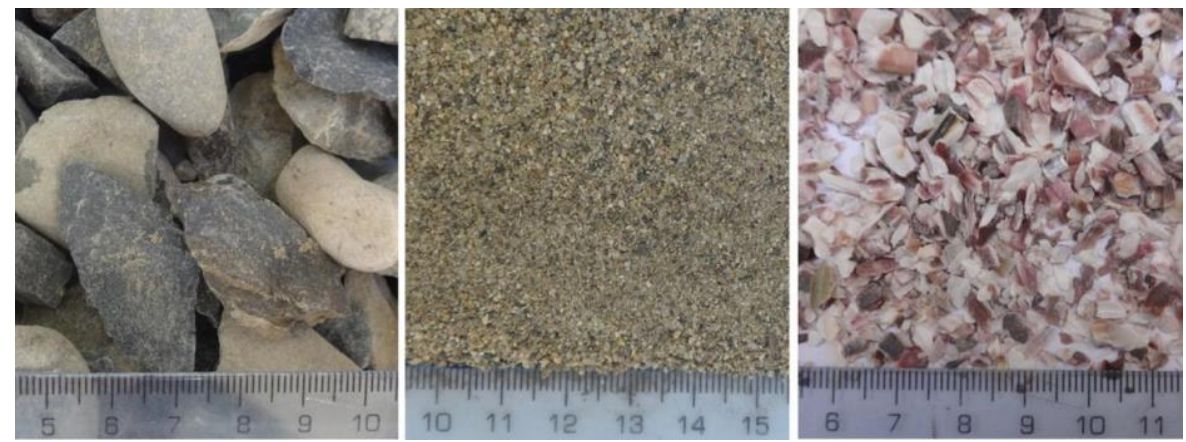

Fig. 4. Aggregates and crushed seashell: Crushed river stone River sand and Crushed seashell [12]

\section{Cockle Shell}

This study focuses on utilizing the marine waste in Malaysia. The cockle shell is used as cementitious material it is similar to the cement given in a Table 1 it shows the physical and chemical properties of cockle shell powder compared with cement. The crushing of cockle shell is similar to the previous study like manual and treatment process [19, 22, 39]. According to ASTMC118, ASTMC136 and ASTMC311 the physical properties are calculated and the chemical properties are analysed by the standard ASTMD5381 [13, 19].

\section{Queen Scallop Shell}

These shells are mostly available in North West France oceanic area. The researchers focus on reuse of marine by product in concrete materials. The shells are crushed using drum compactors and sieving through $10 \mathrm{~mm}$ sieve. The queen scallop shell is used as natural aggregate in concrete mixer Fig. 5 shows the analyses of XRD diffraction of crushed queen shell which indicates the calcite properties reaches maximum in the crystalline phase of the shells. Table 1 Shows the physical and chemical properties of crushed queen scallop shell [4].

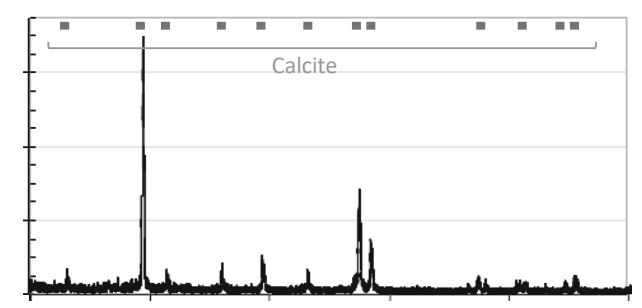

Fig. 5. Analyses of XRD diffraction of crushed queen shell [40]

\section{Coral Reef}

In past 40 decades, utilizing the coral reef from marine islands as aggregate in concrete. The reef aggregate concrete have high compressive strength, low density, high porosity, water absorption, creep shrinkage and chloride resistance is comparatively higher than normal aggregate concrete [22]. The reef concrete is also named as light weight aggregate concrete have higher porosity. The curing process is like normal concrete and the physical properties of coral reef sand is given in Table 1 . 


\section{Clam Shell and Snail Shell}

These shells are available in marine sea shores and in local water bodies. The chemical composition of sea shell is similar to cockle, oyster, mussel and scallop shells. Manufacturing process of clam and snail shells are cleaning $\rightarrow$ drying $\rightarrow$ burning (up to $600^{\circ} \mathrm{C}$ ) $\rightarrow$ crushing $\rightarrow$ grounding $\rightarrow$ sieving (with $200 \mathrm{~mm}$ sieve). The chemical composition of sea shells given a Table 1 and Fig. 6 shows the typical features of clam and snail shells [24, 41, 42].

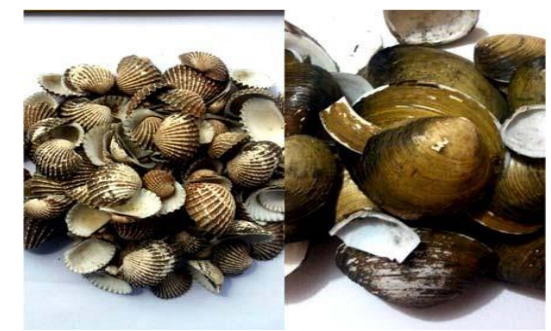

(a)

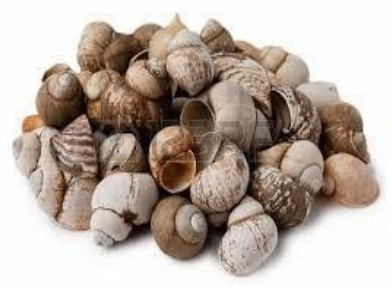

(b)

Fig. 6. Sea shells: (a) clam and (b) snail [25, 42]

\section{CHARACTERIZATION STUDY}

Chemical Properties of Sea Shells

Table 1. The chemical properties of sea shells [41, 43]

\begin{tabular}{llllllllll}
\hline $\begin{array}{l}\text { Chemical } \\
\text { components }\end{array}$ & $\begin{array}{l}\text { Ordinary } \\
\text { Portland } \\
\text { cement }\end{array}$ & $\begin{array}{l}\text { Oyster } \\
\text { Shell }\end{array}$ & $\begin{array}{l}\text { Mussel } \\
\text { Shell }\end{array}$ & $\begin{array}{l}\text { Peruvian } \\
\text { Scallop } \\
\text { Shell }\end{array}$ & $\begin{array}{l}\text { Cockle } \\
\text { Shell }\end{array}$ & $\begin{array}{l}\text { Queen } \\
\text { Scallop } \\
\text { Shell }\end{array}$ & $\begin{array}{l}\text { Coral } \\
\text { Reef } \\
\text { Sand }\end{array}$ & $\begin{array}{l}\text { Clam } \\
\text { Shell }\end{array}$ & $\begin{array}{l}\text { Snail } \\
\text { shell }\end{array}$ \\
\hline $\mathrm{CaCO}_{3}$ & $62-67$ & 95.99 & 94.6 & 53.70 & 51.5 & 50 & 50.46 & 67.70 & 61.95 \\
$\mathrm{SiO}_{2}$ & $17-25$ & 0.69 & 2.58 & 0.10 & 1.37 & 0.2 & 0.42 & 0.39 & 10.20 \\
$\mathrm{Al}_{2} \mathrm{O}_{3}$ & $3-8$ & 0.41 & $<0.01$ & 0.10 & 0.14 & 0.06 & 0.17 & 0.28 & 4.81 \\
$\mathrm{Fe}_{2} \mathrm{O}_{3}$ & $3-4$ & - & $<0.05$ & 0.03 & 1.55 & 0.09 & - & 0.02 & 3.15 \\
$\mathrm{MgO}$ & $1-3$ & 0.64 & 0.27 & 0.18 & 0.18 & 0.1 & 3.1 & - & 0.18 \\
$\mathrm{Na}_{2} \mathrm{O}$ & $0.5-2$ & 0.98 & 0.5 & 0.50 & 0.46 & 0.2 & - & - & 0.25 \\
$\mathrm{~K}_{2} \mathrm{O}$ & $0.5-2$ & - & $<0.06$ & 0.01 & 0.08 & 0.04 & 0.35 & - & 0.20 \\
$\mathrm{SO}_{3}$ & $1-3$ & 0.72 & 0.308 & 0.32 & 0.14 & 0.02 & 0.43 & - & 0.03 \\
\hline
\end{tabular}

Table 1 indicates the chemical properties of sea shells in percentages and comparatively oyster shells, mussel shell, clam shell and Peruvian shells are higher than the conventional cement matrix.

\section{Reaction Mechanism - Pozzolanic Reaction}

In this reaction occur only the siliceous material combine with calcium hydroxide; the reaction changes the cementitious properties. In the development of cement hydration, the calcium silicate hydrate C-S-H and calcium hydroxide $\mathrm{Ca}(\mathrm{OH})_{2}$ is released due to the two components of cement that is Tricalcium silicate $\left(\mathrm{C}_{3} \mathrm{~S}\right)$ and Dicalcium silicate $\left(\mathrm{C}_{2} \mathrm{~S}\right)$ [42]. In this $\mathrm{SiO}_{2}$ and $\mathrm{CaO}$ denotes the $\mathrm{C}$ and $\mathrm{S}$. The cement reaction occurs mainly [16, 29].

$$
2\left(3 \mathrm{CaO} \cdot \mathrm{SiO}_{2}\right)+6 \mathrm{H}_{2} \mathrm{O} \rightarrow 3 \mathrm{CaO} 2 \mathrm{SiO}_{2} 3 \mathrm{H}_{2} \mathrm{O}+3 \mathrm{Ca}(\mathrm{OH})_{2}
$$




$$
\begin{aligned}
& 2\left(2 \mathrm{CaO}_{2} \mathrm{SiO}_{2}\right)+4 \mathrm{H}_{2} \mathrm{O} \rightarrow 3 \mathrm{CaO} 2 \mathrm{SiO}_{2} 3 \mathrm{H}_{2} \mathrm{O}+\mathrm{Ca}(\mathrm{OH})_{2} \\
& 3 \mathrm{CaO} . \mathrm{Al}_{2} \mathrm{O}_{3}+31 \mathrm{H}_{2} \mathrm{O}+3 \mathrm{CaSO}_{4} \rightarrow 3 \mathrm{CaO} . \mathrm{Al}_{2} \mathrm{O}_{3} .3 \mathrm{Ca} \mathrm{SO}_{4} 31 \mathrm{H}_{2} \mathrm{O} \\
& \text { 4CaO. } \mathrm{Al}_{2} \mathrm{O}_{3} . \mathrm{Fe}_{2} \mathrm{O}_{3}+10 \mathrm{H}_{2} \mathrm{O}+2 \mathrm{Ca}(\mathrm{OH})_{2} \rightarrow 6 \mathrm{CaO} . \mathrm{Al}_{2} \mathrm{O}_{3} \cdot \mathrm{Fe}_{2} \mathrm{O}_{3} \cdot 12 \mathrm{H}_{2} \mathrm{O}
\end{aligned}
$$

The equation (1) and (2) is generated by CSH gel hydration process. The equation (3) is generated by $\mathrm{CSH}$ gel hydration product of calcium hydroxide and form a gel like product. The equation (4) generate gel like product having higher volume of calcium hydroxide to improve the compressive strength in cement [14].

\section{Chemical Composition of Marine Shell}

The essential property of carbonate is calcium carbonate. It reacts with other acidic acids and releasing the carbon dioxide, the reaction is $\mathrm{CaCO}_{3}+2 \mathrm{H} \rightarrow \mathrm{Ca}+\mathrm{CO}_{2}+\mathrm{H}_{2} \mathrm{O}$. Due to calcination process by thermal decomposition, the calcium carbonate had been converted into calcium oxide $\mathrm{CaCO}_{3} \rightarrow \mathrm{CaCO}+\mathrm{CO}_{2}$ without calcination process, the calcium carbonate react with water to form calcium bicarbonate $\mathrm{CaCO}_{3}+\mathrm{CO}_{2}+\mathrm{H}_{2} \mathrm{O} \rightarrow \mathrm{Ca}\left(\mathrm{HCO}_{3}\right)_{2}$ [42]. According to the previous research of marine shell chemical properties is mentioned in Table $2 \mathrm{CaO}$ plays an important role in cement concrete. There are larger amount of silicate and aluminates present in sea shells it helps to increase the strength in cement and concrete [15].

\section{Leaching Test}

Is beneficial to use marine shell waste as a construction material has low toxicity, for this kind of shell waste there is no standard leaching tests specimen were found. Only two leaching process available for these shell waste 1. RAW MATERIAL TEST 2. FINAL SPECIMEN TEST As per the standard EN12457-4 the monolith leaching test is conducted [10]. The sea shells are diluted in water up to 1:10 ratio. The materials are evaluated and analysed using (HPLC) High Performance Liquid Chromatography [12]. For the leaching process the wastes are in the form of shells only not in the form of crushed gravel because it does not fall in the limit of specimen, for the classification or separation of sea shell waste as hazardous and non-hazardous material the category of chlorides and sulphates present in it.

Table 2. Result of leaching test of shells samples with reference of EU regulatory limits [37, 39]

\begin{tabular}{lcc}
\hline Parameters & Shells & $\begin{array}{c}\text { Regulatory limits } \\
\text { in EU }\end{array}$ \\
\hline $\mathrm{pH}$ & 8.12 & - \\
Conductivity & 1.16 & - \\
Chromium & $<01$ & 0.5 \\
Copper & $<0.10$ & 2 \\
Zinc & 0.168 & 4 \\
Lead & $<0.01$ & 0.5 \\
Fluoride & 0.275 & 4 \\
Chloride & 147 & 800 \\
Sulphate & 179 & 1000 \\
\hline
\end{tabular}


The range of sulphate $20000 \mathrm{mg} / \mathrm{kg}$ and for chloride $15000 \mathrm{mg} / \mathrm{kg}$ therefore the inserted sample is within in the limit hence the sea shells wastes are non-hazardous material it is recommended for construction work [39, 43]. This testing principle is only for identify the low toxicity materials used in construction. Reference test results of shells are shown in Table 2. Table 2 indicates that the parameters study of the sea shells with High Performance Liquid Chromatography (HPLC) and results in comparison of regulatory limits and it shows the sea shells are non-toxic material for environmental concern.

\section{Acoustic Properties}

Identifying the sound absorption coefficient $(\alpha)$ in material or its surface related with transmitted energy, absorbed energy and incident energy, when a sound wave occur on a sample material according to ISO 10534-2 and ASTM E1050 for testing the sound wave inserted into the tube it contains specimens and the specimens are covered with petroleum jelly as per ISO 10534-2 [37, 44]. The sound energy is absorbed in microphones it attached to the tube. After recording the acoustic pressure and converted into the ACUPRO software. This software measures the sound absorption coefficient of a specimen for the building material analysis, the specimen is calculated according to ISO 11654(ISO 1998) 250, 500, 1000,2000 and $4000 \mathrm{~Hz}$ of frequencies curves [37, 44]. The result of sound absorption coefficient is given in Table 3 [12]. For common building materials the optimum absorption value about $0.3-0.8$ for frequency $500 \mathrm{~Hz}$, From the Table 3 the frequencies ranges and values are proven that, the recycle sea shells are valuable material for construction.

Table.3 The result of sound absorption coefficient of sea shells [12]

\begin{tabular}{cc}
\hline Frequency $(\mathrm{Hz})$ & Value \\
\hline 250 & 0.80 \\
500 & 1.0 \\
1000 & 1.0 \\
2000 & 1.0 \\
4000 & 0.90 \\
\hline
\end{tabular}

\section{Thermogravimetric Analysis (TGA)}

Thermogravimetric analysis testing conducted with mussel shells, oyster shells and cockle shells at the different temperature of $200^{\circ} \mathrm{C}-356^{\circ} \mathrm{C}, 356^{\circ} \mathrm{C}-600^{\circ} \mathrm{C}, 600^{\circ} \mathrm{C}-850^{\circ} \mathrm{C}$ respectively $[16,45]$. During this temperature treatment process, the shells react with oxidation process and its release the organic matter and results in loss of weight in sea shells [17]. At minimum temperature of $200^{\circ} \mathrm{C}$, the weight of mussel shells reduced up to $0.4 \%$. In temperature $200^{\circ} \mathrm{C}-356^{\circ} \mathrm{C}$ weight loss up to $1.7 \%$ Gradually the temperature increases about $600-856^{\circ} \mathrm{C}$, the weight loss up to $43.3 \%$ [11]. Similarly, the TGA analysis conducted for oyster shell and cockle shells, it results in reduction in weight it is comparatively equal to conventional limestone [46, 47]. From this thermos gravimetric analysis, the $\mathrm{CaO}$ content in sea shells are observed. Fig. 7 a shows the thermos gravimetric analysis of mussel shells and Fig. $7 \mathrm{~b}$ shows the thermos gravimetric analysis of oyster shells. 
a)

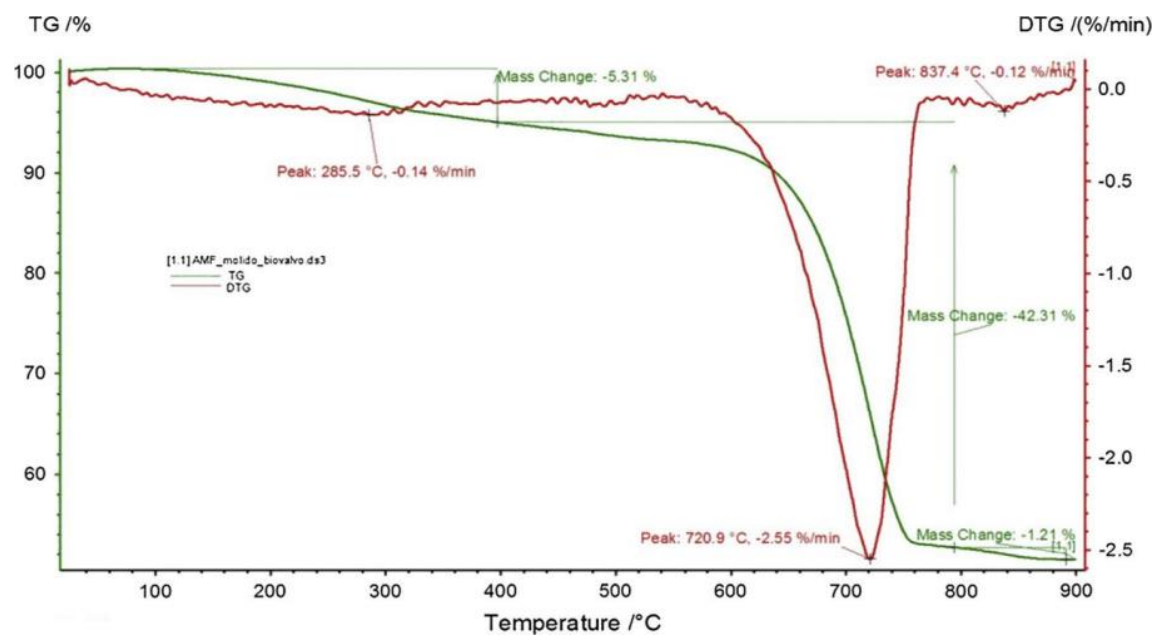

b)

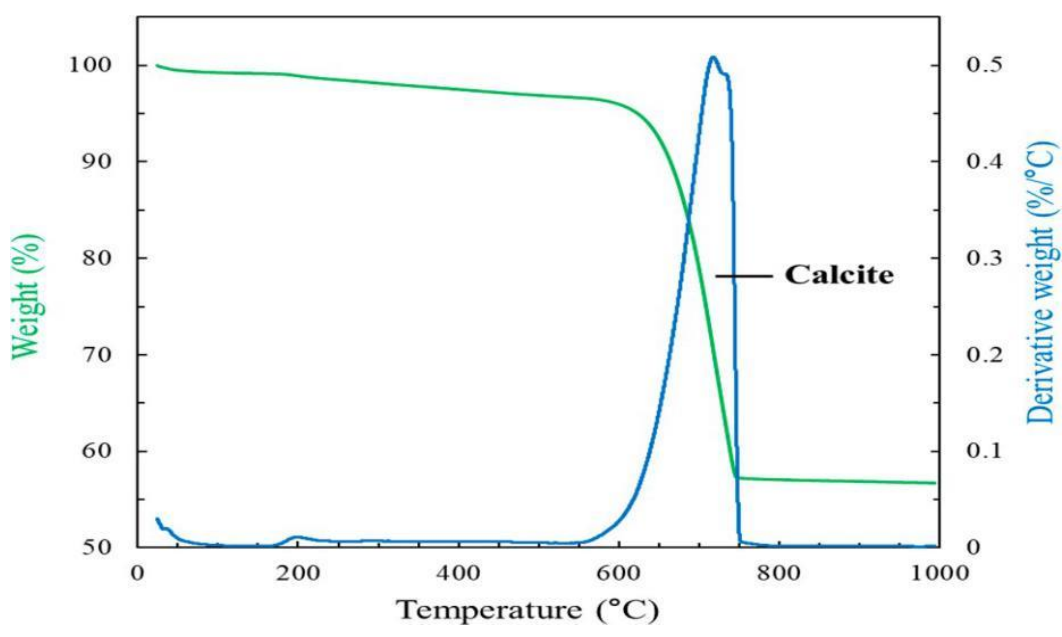

Fig. 7. (a) Thermogravimetric Analysis (TGA) of mussel shell [11, 45],

(b) thermogravimetric Analysis (TGA) of oyster shell [18]

\section{Microstructure}

Concrete has a components of cement, fine aggregate and course aggregate combination with heterogeneous structure, the three phases are in transition zone. The microstructure study is conducted to understand the behaviour of cement and aggregates in hydration process. Three dimensional views of the materials identify the chemical composition of hydration in irregular shape of the materials. According to previous research, the structure of seashells is divided into three parts [48]. Periostracum layer, Prismatic layer, and Nacre layers indicate the outer, middle, and inner layers of shells [11]. From the SEM analysis result, the overall shell morphology was observed. The shape of the materials, internal structures of the material, slender particles, and prismatic layer of calcium carbonate are recorded. Fig. 8 a shows the inner layer of the mussel shell [40]. Fig. 8 b shows the inner layer of the oyster shell [40]. Fig. 8 c shows the shape and size of mussel, cockle, and clamshells recorded in SEM analysis [20]. Figures $8 \mathrm{a}$ and $\mathrm{b}$ show the crystalline microstructure of material with indication of bulkiness, needle shape crystal, plate like crystal forms in interfaces of materials. From the SEM and XRD results the sea shells are irregular in 
shapes with plate needle phases that becomes cement paste and aggregates are highly binds with better hydration process.

a)

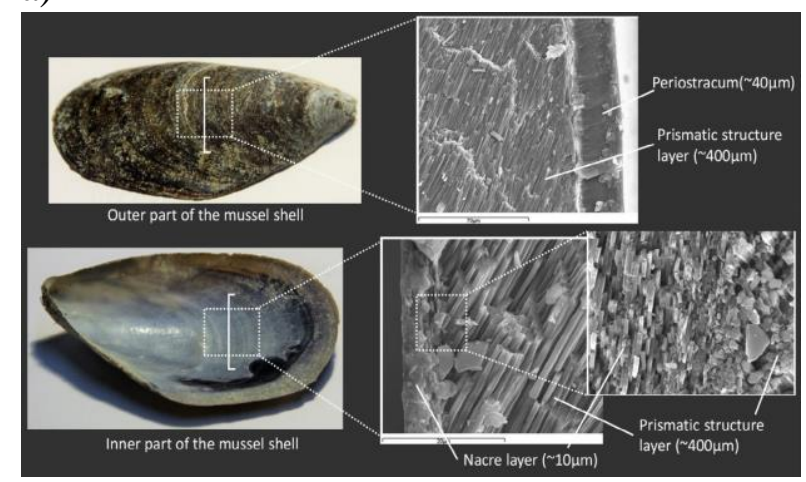

b)
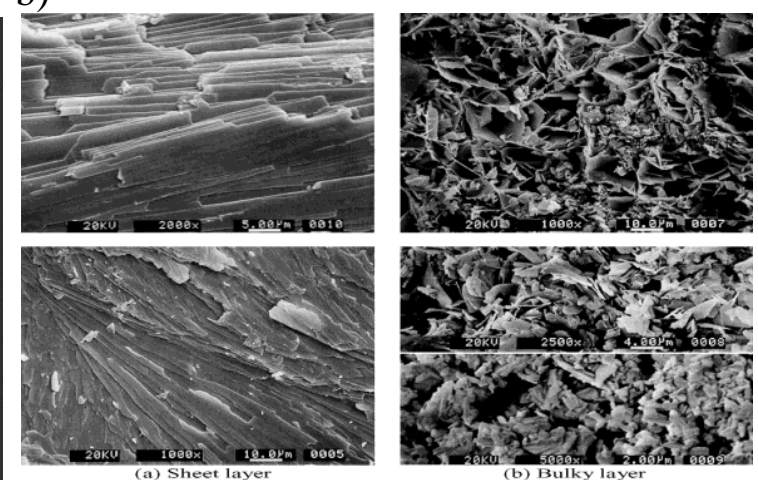

c)
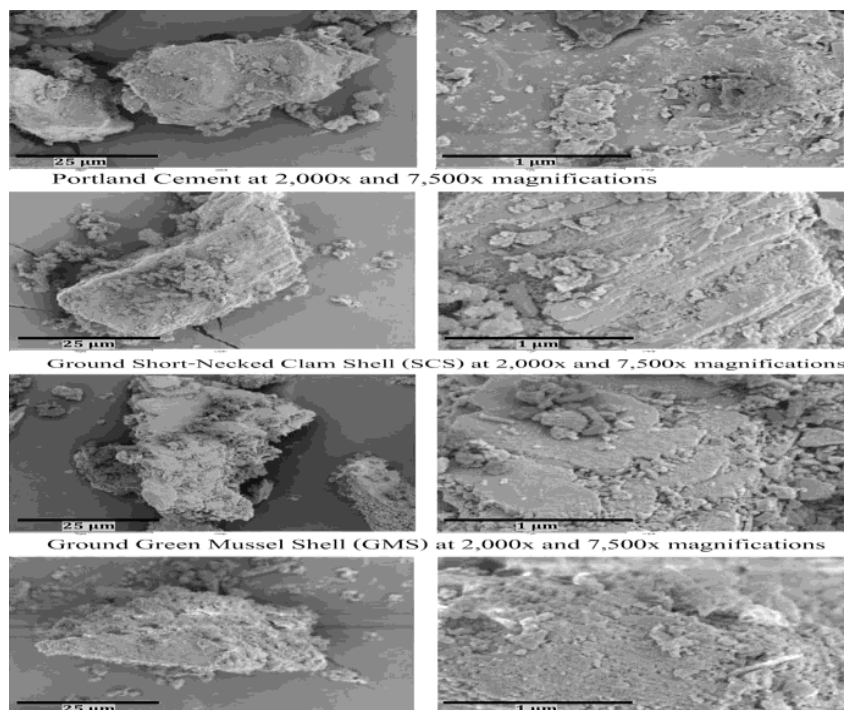

at $2,000 \times$ and $7,500 \times$ magnifications
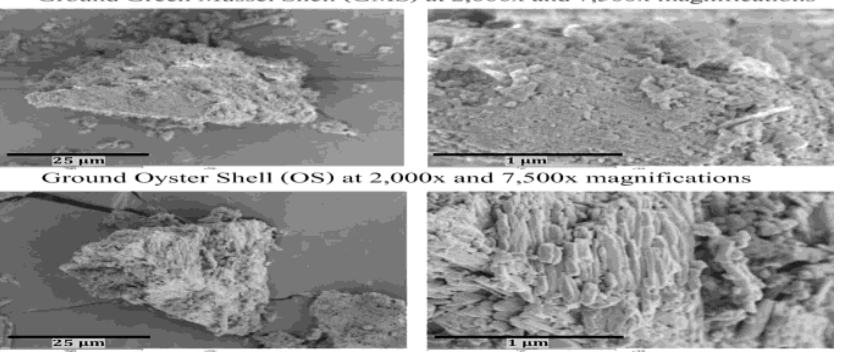

$\mathrm{x}$ and $7,500 \mathrm{x}$ magnifications

Ground Cockle Shell (CS) at 2,000x and 7,500x magnifications

Fig. 8. (a) Shows the inner layer of the mussel shell [40], (b): the inner layer of the oyster shell [40],

(c) the shape and size of mussel, cockle and clam shells recorded in SEM analysis [20]

\section{Physical Properties}

Marine sea shells have been used as the replacement of construction material for the fine aggregate and coarse aggregate with minimum particle size of $5 \mathrm{~mm}$ from the Table 4 compared to normal sand, the seashells particle size are similar. The particle size are more than $10-15 \mathrm{~mm}$ that shells are used as the coarse aggregate [48]. Specific gravity of shell also similar to the normal aggregate with the range of 2.57-2.76 as shown in Table 4 [16]. Since the calcium carbonate content are higher in marine shells that increases the specific gravity of the shell up to 4.8 [21].Water absorption are recorded 1.88-1.20 in Table 4 due to the irregular shape and internal pores surface of the shells [48]. 
Table 4. Physical properties of sea shells [48]

\begin{tabular}{lcc}
\hline \multicolumn{1}{c}{ Characteristics } & Crushed Sea shell & $\begin{array}{c}\text { Crushed sea shell } \\
\text { gravel }\end{array}$ \\
\hline Fineness Modulus & 4.57 & - \\
Specific Gravity & 2.57 & 2.76 \\
Absorption & 1.88 & 1.20 \\
Water Content & 0.38 & 0.70 \\
Maximum Particle Size & 4.76 & 25.4 \\
Chloride & 0.0139 & 0.0063 \\
Organic Matter Content & 1.03 & - \\
Sulphate content & 0.0146 & 0.0119 \\
\hline
\end{tabular}

\section{RESULTS AND DISCUSSION}

\section{Effects on fresh concrete}

\section{- Workability}

The overview of seashells waste involvement in workability of mortar and concrete is reduced due to porous, particle size and irregular shapes of the shells [28, 49]. The irregular shape of the shells causes high friction in material, it results in decrease in workability. The high level contribution of oyster shell as fine aggregate in concrete observed that reduction in workability in fresh concrete test $[28,50]$. Sea shells containing organic matters that may increases the paste viscosity, and hence decrease the slump value. The sea shells replaced as coarse aggregate instead of fine aggregate, it results in improve the workability up to $12.5 \%$ level of replacement $[41,51]$. Periwinkle shells are replaced as coarse aggregate up to $50 \%$ and is result in $90 \%$ of workability recorded. As per the previous researches, the sea shells are used as fine aggregate about $05-20 \%$, they obtained optimum strength and flow. Instead of fine aggregate the shells are used as coarse aggregate about $40-50 \%$ with add on admixtures the result shows the $90 \%$ of slump value. Based on the types of shells, specific gravity, particle size and surface area of the shells increase the workability of fresh concrete [40].

\section{- Setting times}

When crushed sea shells waste were used as fine aggregate up to $20 \%$ the heat of hydration is delay due to water absorption of sea shells are increased [38]. Heat of hydration and setting time delayed due to the pressure of organic matter and water absorption in seashells. In mussel shells the presence of natural polysaccharide mineral improves the setting time of the mortar [16, 52]. Same as oyster shell powder are add on with diatomaceous material and result in decrease of setting time due to reaction formation of calcium silicate hydrate gel. Replacement of ground shells as followed for $20 \%$ the researchers observed as decreases in setting time of mortar and concrete [20]. 


\section{- Air content}

Fig. 9 shows the report of air content present in the crushed shells [16]. Presence of sea shells as coarse aggregate or fine aggregate up to $50-60 \%$ of replacement increase the entrapped air in the fresh concrete due to presence of organic matters and irregular shape of the shells [23]. Air bubbles formed in the concrete due to organic substances the voids increased 2-5.6\% when the oyster shell added to the concrete and also study the porous nature of the shells [8]. Reduce the organic matter in sea shells with chemical process and it may work out with reduction of porous in concrete from the previous study the replacement limits up to $20 \%$. Fig. 9 a shows the SEM image of concrete without oyster shell and Fig. 9 b shows the SEM image of concrete with oyster shell [16].

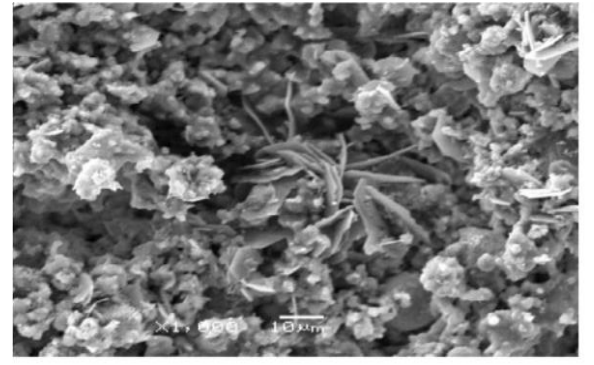

(a) 7 days

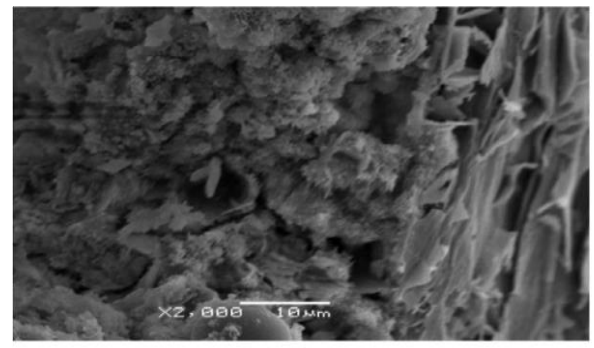

(a) 7 days

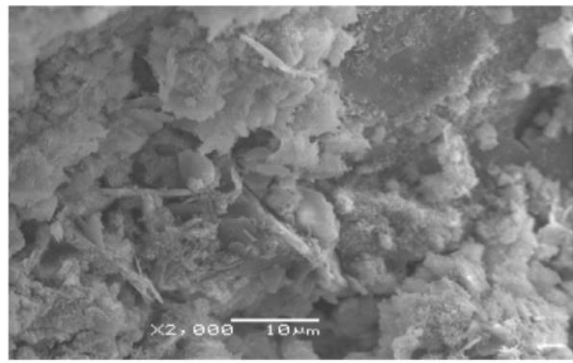

(b) 28 days

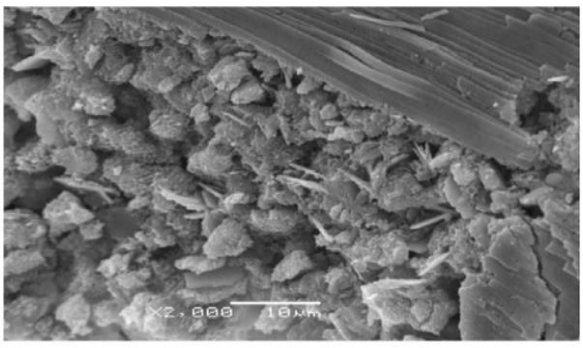

(b) 28 days

Fig. 9. SEM image of concrete (a) without oyster shell, (b) with oyster shell [16]

The air content study shows the pores in concrete with crushed shells and without crushed shells in the magnification of $2000 \mathrm{X}$, the figures indicates the sea shell concrete are irregular in shape it increases the binding of cement and aggregate in hydration process.

\section{Effects on Hardened Concrete}

\section{- Density}

Based on the previous research oyster shells, mussel shells, scallop shells and ground shells are used as aggregate replacement material, researchers observed a few difference in density of concrete[24, 42]. Density of the material based on the specific gravity of the material, sea shells are having specific gravity is comparatively equal to normal concrete. Even through the presence of organic matters and irregular shapes of shells caused entrapped air in concrete and results in reduction of density [53, 54]. Shells are replaced for fine aggregate in mortar which increases the density due to specific gravity is equal to fine aggregate. 
- Compressive strength

Table 5. The compressive strength of sea shells [55-57]

\begin{tabular}{cccccc}
\hline $\begin{array}{c}\text { Category } \\
\text { of sea } \\
\text { shells }\end{array}$ & $\begin{array}{c}\text { Replacement } \\
\text { material for } \\
\text { cement / } \\
\text { concrete }\end{array}$ & $\begin{array}{c}\text { Percentage } \\
\text { of } \\
\text { replacement }\end{array}$ & $\begin{array}{c}\text { Possible compressive } \\
\text { strength for control } \\
\text { sample (MPa) at 28 } \\
\text { days }\end{array}$ & Grade & $\begin{array}{c}\text { Observed } \\
\text { compressive } \\
\text { strength (MPa) at } \\
\text { 28 days }\end{array}$ \\
\hline Oyster & Concrete & $15 \%$ & 17.5 & M30 & 16.5 \\
Peruvian & Concrete & $10 \%$ & 17.5 & M30 & 19 \\
Cockle & Concrete & $5 \%$ & 36.5 & M30 & 36 \\
Clam & Concrete & $5 \%$ & 37.0 & M30 & 39.8 \\
Snail & Concrete & $10 \%$ & 17.5 & M30 & 18 \\
Mussel & $\begin{array}{c}\text { Cement } \\
\text { Mortar }\end{array}$ & $5 \%$ & 43.04 & M25 & 38.3 \\
Mollusc & $\begin{array}{c}\text { Cement } \\
\text { Mortar }\end{array}$ & $5 \%$ & 43.04 & M25 & 39.5 \\
Oyster & $\begin{array}{l}\text { Cement } \\
\text { Mortar }\end{array}$ & $5 \%$ & 43.04 & M25 & 37.5 \\
Cockle & $\begin{array}{l}\text { Cement } \\
\text { Mortar }\end{array}$ & $5 \%$ & 14.9 & M25 & 12.6 \\
Clam & Cement & $5 \%$ & 14.9 & M25 & 13 \\
\hline
\end{tabular}

The effects of marine waste shells contribution as fine aggregate, coarse aggregate and cement replacement on $28^{\text {th }}$ day of compressive strength is tabulated. In higher replacement level of shells in concrete reduce the compressive strength of concrete. Due to poor bonding between cement and aggregate paste, the compressive strength decreased [50, 52]. Fig. 10 shows the bonding between cement and oyster shell paste. Fig. 11 shows the bonding nature of the mussel shell [27].

a)

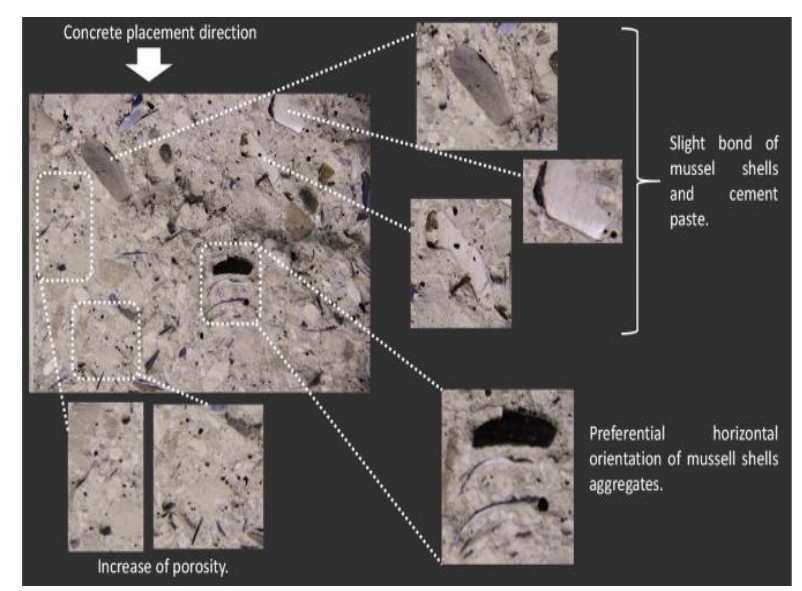

b)

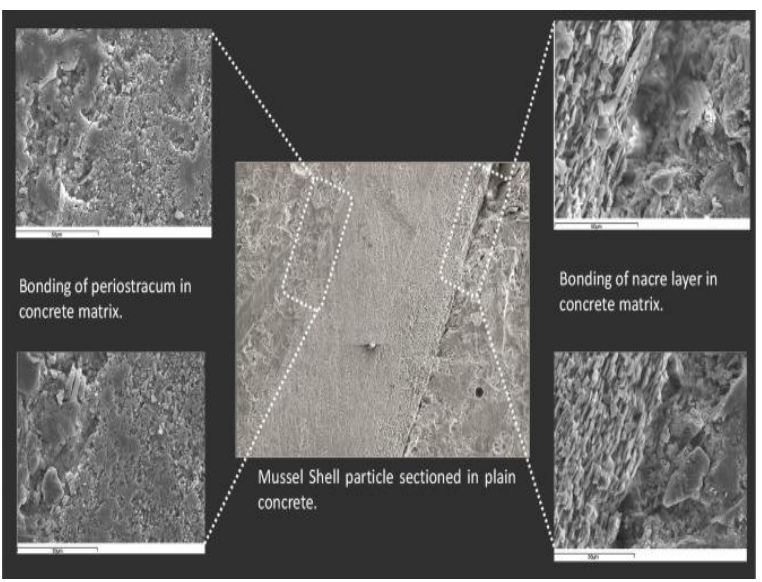

Fig. 10. (a) Bonding between cement Oyster shell paste [27], (b) Bonding nature of mussel Shells [58] 
For the compressive strength analysis for concrete and cement there are different types of sea shells waste materials had been studied by various researchers [28]. The compressive strength of Peruvian and clam is comparatively higher than the other shells at the age of 28 days of curing $19 \mathrm{MPa}$ and $39.8 \mathrm{MPa}$ respectively [29]. And these shells concrete compressive strength have increased than the possible rate of compressive strength which is given in a Table $5[53,54,57]$. And clam shell concrete records higher compressive strength with least percentage of replacement about 5\%. For other sea shells the replacement percentage is increase the concrete strength is also increases [39, 59]. A strength reduced up to $19 \%$ which the cockle shell is replaced about $25 \%$ of fine aggregate [21]. Compare to coarse aggregate replacement of fine aggregate gave better interlocking effects with concrete. As per the researchers we can conclude the waste sea shells are suitable for concrete material. Even through Compressive strength is decreased compared with normal concrete due to porous present in concrete hence the shells are made as higher fine powder and adding with cement results in perfect bonding with concrete and becomes a perfect filler material [60]. The oyster shell powder reacts with cement, calcium hydroxide is released due to heat of hydration process same as mussel shell, cockle shells are replaced as cement content in concrete blocks, and the $40 \%$ of the compressive strength will be reduced. The cement replacement up to $20 \%$ increases the compressive strength of concrete. Only few researchers had been studied the benefits of sea shell as replacement material in cement with effective filling voids [30, 61-64]. From the Table 5 the observed value of compressive strength for cement mortar is applicable with optimum usage of oyster, clam, mussel, cockle shells about 4-5 percentage [28]. Based on the researchers study the waste sea shells are given optimum compressive strength.

\section{- Flexural strength}

Based on the chemical composition of material the flexural strength is increases in concrete. From the Table1 Sea shells are contains highest range of calcium content which is essential for bonding process in concrete it is comparatively higher than the ordinary Portland cement $[60,61]$. Calcium content in cement increases the bonding between aggregate and cement paste in concrete. Range from 4.5-6.75 $\mathrm{MPa}$ of flexural strength in sea shells is observed [29]. The flexural strength of ordinary Portland cement and ordinary Portland cement with sea shells is gradually increases in 7, 28 and 91 days [15]. In 7days curing the strength of OPC [14]. OPC + SS is similar after 7 days the flexural strength is increases gradually up to $6.75 \mathrm{MPa}$ [29].

\section{- Tensile strength}

As per the literature study utilization of marine waste sea shell as a construction material with proper concrete mix design ratio samples are batched and cured, these sea shell concrete cubes are taking longer duration for curing. Due to the longer duration of the curing process, the concrete strength has been increased. [27, 62]. curing process take an important role in hydration of cement process with water, during hydration process of cement the pozzolanic reactions improves the concrete strength [65]. Tensile strength of the concrete increases when the curing time is increases, similarly the tensile strength based on the compressive strength of concrete. Cockle shell concrete increase the tensile strength compared to possible concrete tensile strength value $[29,66]$. Large type of shells is obtained low tensile strength and the fine powder of shells increases the strength. Same as cockle shell ash also act as the suitable material for cement mortar to increase the tensile strength with minimum percentage of replacement. As per the previous research, Clam shell concrete also reach the tensile strength about $3.25 \mathrm{MPa}[54,58]$. Is equal or higher than the possible control sample value in 28 and 90 days. 


\section{SUMMARY}

The marine waste shells are collected from fisheries processing the shells are treated by using manual and machine then it is used as fine and course aggregate in concrete with a standard size which is recommended in IS 383(1970), the cockle shell, mussel shells, oyster shells performance as slightly increased compared to calm shell, snail shell and Peruvian shell. The Mechanical properties of concrete strength are gradually increased in harden stage. For fresh concrete analysis, workability in seashell fine aggregates is better than the seashell coarse aggregate. Even though there is a delay in setting time and air content in concrete is quite increased due to its organic components. For strength basis, the harden tests of concrete are conducted. The compressive strength, flexural strength and tensile strength are achieved $80 \%$ of results from conventional concrete by the (cube specimens and cylinder specimens). The density of the sample specimens is similar to the traditional concrete, and the interface studies are conducted for each shell to understand the mechanism of cement, fine aggregate, and coarse aggregate reacts with concrete. Overall the sea shells are best performing raw material in concrete.

From the literature review, this study focus on the reuse of marine bio-refinery waste shells as a replacement material in the construction field. Development of sustainable, ecofriendly material in concrete technology, using economic and ecological waste material to produce green concrete, eco-friendly cement and improve waste management. Utilizing the various types of seashells in concrete has been concluded as a suitable material for construction with achieved Mechanical Properties, Chemical Properties, Physical Properties, and Interfacial components. Seashells are replaced for coarse aggregate about $20 \%$, there are identical results in mechanical properties compared to conventional coarse aggregate, and the seashells are replaced as fine aggregate in concrete up to $30 \%$, the effects in the mechanism of fine aggregate and coarse aggregate are superior results in physical and mechanical properties of concrete. The cost and the manufacturing process of the materials are inexpensive. All the performance of shells act as the raw material in concrete furnish with satisfactory outcome hence the waste marine bio-refinery wastes are endorsing for construction.

For the future need of eco-friendly material researcher's focus on green building material research with seashells, and such research is useful to reducing the waste landfilling and encouraging the natural waste utilization of green concrete material. Further research of seashells to analysis the performance of the sea shell concretes in long term test, short term tests and energy analysis since it is concluded as a valuable green material for construction.

\section{REFERENCES}

1. B. Safi, M. Saidi, A. Daoui, A. Bellal, A. Mechekak, and K. Toumi, "The use of seashells as a fine aggregate (by sand substitution) in self-compacting mortar (SCM)," Constr. Build. Mater., vol. 78, pp. 430-438, 2015, doi: 10.1016/j.conbuildmat.2015.01.009.

2. W. A. S. Bin Wan Mohammad, N. H. Othman, M. H. Wan Ibrahim, M. A. Rahim, S. Shahidan, and R. A. Rahman, "A review on seashells ash as partial cement replacement," IOP Conf. Ser. Mater. Sci. Eng., vol. 271, no. 1, pp. 1-8, 2017, doi: 10.1088/1757899X/271/1/012059.

3. P. Ballester, I. Mármol, J. Morales, and L. Sánchez, "Use of limestone obtained from waste of 
the mussel cannery industry for the production of mortars," Cem. Concr. Res., vol. 37, no. 4, pp. 559-564, 2007, doi: 10.1016/j.cemconres.2007.01.004.

4. B. Peceño, C. Arenas, B. Alonso-Fariñas, and C. Leiva, "Substitution of Coarse Aggregates with Mollusk-Shell Waste in Acoustic-Absorbing Concrete," J. Mater. Civ. Eng., vol. 31, no. 6, p. 04019077, 2019, doi: 10.1061/(asce)mt.1943-5533.0002719.

5. G. L. Yoon, B. T. Kim, B. O. Kim, and S. H. Han, "Chemical-mechanical characteristics of crushed oyster-shell," Waste Manag., vol. 23, no. 9, pp. 825-834, 2003, doi: 10.1016/S0956053X(02)00159-9.

6. K. N. R. F. C. Venkata Sai Nagendra, C. Venkata Siva Rama Prasad, "An Experimental Investigation On Properties Of Concrete By Partial Replacement Of Cement With Dolomite And Sand With Crushed Sea Shell," Int. J. Sci. Technol. Res. Vol. 8, ISSUE 10, Oct. 2019 ISSN 2277-8616, vol. 43, no. July, pp. 1325-1330, 2020, doi: 10.1016/j.matpr.2020.09.164.

7. E. Gartner and H. Hirao, "A review of alternative approaches to the reduction of $\mathrm{CO} 2$ emissions associated with the manufacture of the binder phase in concrete," Cem. Concr. Res., vol. 78, pp. 126-142, 2015, doi: 10.1016/j.cemconres.2015.04.012.

8. F. Soltanzadeh, M. Emam-Jomeh, A. Edalat-Behbahani, and Z. Soltan-Zadeh, "Development and characterization of blended cements containing seashell powder," Constr. Build. Mater., vol. 161, pp. 292-304, 2018, doi: 10.1016/j.conbuildmat.2017.11.111.

9. G. K. M. Subramanian, M. Balasubramanian, and A. A. Jeya Kumar, "A Review on the Mechanical Properties of Natural Fiber Reinforced Compressed Earth Blocks," J. Nat. Fibers, vol. 00, no. 00, pp. 1-15, 2021, doi: 10.1080/15440478.2021.1958405.

10. C. Rahul Rollakanti, C. Venkata Siva Rama Prasad, K. K. Poloju, N. M. Juma Al Muharbi, and Y. Venkat Arun, "An experimental investigation on mechanical properties of concrete by partial replacement of cement with wood ash and fine sea shell powder," Mater. Today Proc., vol. 43, no. April, pp. 1325-1330, 2020, doi: 10.1016/j.matpr.2020.09.164.

11. F. C. Lo, S. L. Lo, and M. G. Lee, "Effect of partially replacing ordinary Portland cement with municipal solid waste incinerator ashes and rice husk ashes on pervious concrete quality," Environ. Sci. Pollut. Res., vol. 27, no. 19, pp. 23742-23760, 2020, doi: 10.1007/s11356-020-08796-z.

12. N. Mikanovic, K. Khayat, M. Pagé, and C. Jolicoeur, "Aqueous $\mathrm{CaCO} 3$ dispersions as reference systems for early-age cementitious materials," Colloids Surfaces A Physicochem. Eng. Asp., vol. 291, no. 1-3, pp. 202-211, 2006, doi: 10.1016/j.colsurfa.2006.06.042.

13. Y. M. H. Mustafa, O. S. B. Al-Amoudi, S. Ahmad, M. Maslehuddin, and M. H. Al-Malack, "Utilization of Portland cement with limestone powder and cement kiln dust for stabilization/solidification of oil-contaminated marl soil," Environ. Sci. Pollut. Res., vol. 28, no. 3, pp. 3196-3216, 2021, doi: 10.1007/s11356-020-10590-w.

14. D. Chen, P. Zhang, T. Pan, Y. Liao, and H. Zhao, "Evaluation of the eco-friendly crushed waste oyster shell mortars containing supplementary cementitious materials," J. Clean. Prod., vol. 237, p. 117811, 2019, doi: 10.1016/j.jclepro.2019.117811.

15. T. Sato and F. Diallo, "Seeding effect of nano-CaCO3 on the hydration of tricalcium silicate," Transp. Res. Rec., no. 2141, pp. 61-67, 2010, doi: 10.3141/2141-11.

16. C. H. Tsou et al., "Rendering polypropylene biocomposites antibacterial through modification with oyster shell powder," Polymer (Guildf)., vol. 160, pp. 265-271, 2019, doi: 10.1016/j.polymer.2018.11.048.

17. T. H. Silva, J. Mesquita-Guimarães, B. Henriques, F. S. Silva, and M. C. Fredel, "The potential use of oyster shell waste in new value-added by-product," Resources, vol. 8, no. 1, pp. 1-15, 2019, doi: 10.3390/resources8010013.

18. M. Huang, H. Feng, N. Li, D. Shen, Y. Zhou, and Y. Jia, "Addition of large amount of 
municipal sewage sludge as raw material in cement clinker production," Environ. Sci. Pollut. Res., vol. 24, no. 36, pp. 27862-27869, 2017, doi: 10.1007/s11356-017-9949-6.

19. A. Edalat-Behbahani, F. Soltanzadeh, M. Emam-Jomeh, and Z. Soltan-Zadeh, "Sustainable approaches for developing concrete and mortar using waste seashell," Eur. J. Environ. Civ. Eng., vol. 25, no. 10, pp. 1874-1893, 2021, doi: 10.1080/19648189.2019.1607780.

20. A. Ahmed, S. Guo, Z. Zhang, C. Shi, and D. Zhu, "A review on durability of fiber reinforced polymer (FRP) bars reinforced seawater sea sand concrete," Constr. Build. Mater., vol. 256, p. 119484, 2020, doi: 10.1016/j.conbuildmat.2020.119484.

21. G. Del, Á. El, T. Lagunillas, F. Valeriano, E. Algodón, and F. L. A. Totora, "Study of compressive strength characteristics of coral aggregate concrete," no. 270, p. 2305, 2013.

22. S. Motamedi, S. Shamshirband, R. Hashim, D. Petković, and C. Roy, "Estimating unconfined compressive strength of cockle shell-cement-sand mixtures using soft computing methodologies," Eng. Struct., vol. 98, pp. 49-58, 2015, doi: 10.1016/j.engstruct.2015.03.070.

23. T. A. Dang, S. Kamali-Bernard, and W. A. Prince, "Design of new blended cement based on marine dredged sediment," Constr. Build. Mater., vol. 41, pp. 602-611, 2013, doi: 10.1016/j.conbuildmat.2012.11.088.

24. Q. Wang, P. Li, Y. Tian, W. Chen, and C. Su, "Mechanical properties and microstructure of Portland cement concrete prepared with coral reef sand," J. Wuhan Univ. Technol. Mater. Sci. Ed., vol. 31, no. 5, pp. 996-1001, 2016, doi: 10.1007/s11595-016-1481-x.

25. J. M. Gao, C. X. Qian, H. F. Liu, B. Wang, and L. Li, "ITZ microstructure of concrete containing GGBS," Cem. Concr. Res., vol. 35, no. 7, pp. 1299-1304, 2005, doi: 10.1016/j.cemconres.2004.06.042.

26. D. H. K. Prasad and C. V. S. R. Prasad, "Review Paper on the Effect of Microbiologically induced $\mathrm{CaCO} 3$ Precipitation on Self healing Method of Concrete : Bacterial concrete," vol. 5, no. Xii, pp. 1045-1049, 2017.

27. D. Wang, H. Wang, S. Larsson, M. Benzerzour, W. Maherzi, and M. Amar, "Effect of basalt fiber inclusion on the mechanical properties and microstructure of cement-solidified kaolinite," Constr. Build. Mater., vol. 241, p. 118085, 2020, doi: 10.1016/j.conbuildmat.2020.118085.

28. S. Cheng, Z. Shui, T. Sun, R. Yu, G. Zhang, and S. Ding, "Effects of fly ash, blast furnace slag and metakaolin on mechanical properties and durability of coral sand concrete," Appl. Clay Sci., vol. 141, pp. 111-117, 2017, doi: 10.1016/j.clay.2017.02.026.

29. W. Kurdowski, "The protective layer and decalcification of C-S-H in the mechanism of chloride corrosion of cement paste," Cem. Concr. Res., vol. 34, no. 9, pp. 1555-1559, 2004, doi: 10.1016/j.cemconres.2004.03.023.

30. G. Rajasekaran, "Sulphate attack and ettringite formation in the lime and cement stabilized marine clays," Ocean Eng., vol. 32, no. 8-9, pp. 1133-1159, 2005, doi: 10.1016/j.oceaneng.2004.08.012.

31. F. Martirena and J. Monzó, "Vegetable ashes as Supplementary Cementitious Materials," Cem. Concr. Res., vol. 114, no. November 2016, pp. 57-64, 2018, doi: 10.1016/j.cemconres.2017.08.015.

32. E. Aprianti, P. Shafigh, S. Bahri, and J. N. Farahani, "Supplementary cementitious materials origin from agricultural wastes - A review," Constr. Build. Mater., vol. 74, pp. 176-187, 2015, doi: 10.1016/j.conbuildmat.2014.10.010.

33. D. Wang, Q. Zhao, C. Yang, Y. Chi, W. Qi, and Z. Teng, "Study on frost resistance and vegetation performance of seashell waste pervious concrete in cold area," Constr. Build. Mater., vol. 265, p. 120758, 2020, doi: 10.1016/j.conbuildmat.2020.120758. 
34. A. Naqi, S. Siddique, H. K. Kim, and J. G. Jang, "Examining the potential of calcined oyster shell waste as additive in high volume slag cement," Constr. Build. Mater., vol. 230, p. 116973, 2020, doi: 10.1016/j.conbuildmat.2019.116973.

35. J. H. Seo, S. M. Park, B. J. Yang, and J. G. Jang, "Calcined oyster shell powder as an expansive additive in cement mortar," Materials (Basel)., vol. 12, no. 8, 2019, doi: 10.3390/ma12081322.

36. R. K. Etim, I. C. Attah, and P. Yohanna, "Experimental study on potential of oyster shell ash in structural strength improvement of lateritic soil for road construction," Int. J. Pavement Res. Technol., vol. 13, no. 4, pp. 341-351, 2020, doi: 10.1007/s42947-020-0290-y.

37. F. Marin, N. Le Roy, and B. Marie, "2. MOLLUSK SHELL 2.1. Introduction," pp. 10991125, 2012.

38. K. C. Panda, S. Behera, and S. Jena, "Effect of rice husk ash on mechanical properties of concrete containing crushed seashell as fine aggregate," Mater. Today Proc., vol. 32, no. 4, pp. 838-843, 2020, doi: 10.1016/j.matpr.2020.04.049.

39. C. Martínez-García, B. González-Fonteboa, F. Martínez-Abella, and D. Carro- López, "Performance of mussel shell as aggregate in plain concrete," Constr. Build. Mater., vol. 139, pp. 570-583, 2017, doi: 10.1016/j.conbuildmat.2016.09.091.

40. H. Cuadrado-Rica, N. Sebaibi, M. Boutouil, and B. Boudart, "Properties of ordinary concretes incorporating crushed queen scallop shells," Mater. Struct. Constr., vol. 49, no. 5, pp. 18051816, 2016, doi: 10.1617/s11527-015-0613-7.

41. J. Burt, A. Bartholomew, A. Bauman, A. Saif, and P. F. Sale, "Coral recruitment and early benthic community development on several materials used in the construction of artificial reefs and breakwaters," J. Exp. Mar. Bio. Ecol., vol. 373, no. 1, pp. 72-78, 2009, doi: 10.1016/j.jembe.2009.03.009.

42. B. A. Tayeh, M. W. Hasaniyah, A. M. Zeyad, and M. O. Yusuf, "Properties of concrete containing recycled seashells as cement partial replacement: A review," J. Clean. Prod., vol. 237, p. 117723, 2019, doi: 10.1016/j.jclepro.2019.117723.

43. Mahdi Majedi-Asl and Robabeh Jafari, "The Mathematical Modeling of Self-Purification of the Zarjoob River for Justification of Emission,” J. Environ. Sci. Eng., vol. 1, no. 1, 2012.

44. C. Arenas, C. Leiva, L. F. Vilches, and H. Cifuentes, "Use of co-combustion bottom ash to design an acoustic absorbing material for highway noise barriers," Waste Manag., vol. 33, no. 11, pp. 2316-2321, 2013, doi: 10.1016/j.wasman.2013.07.008.

45. K. H. Mo, U. J. Alengaram, M. Z. Jumaat, S. C. Lee, W. I. Goh, and C. W. Yuen, "Recycling of seashell waste in concrete: A review," Constr. Build. Mater., vol. 162, no. February, pp. 751-764, 2018, doi: 10.1016/j.conbuildmat.2017.12.009.

46. A. Abdelouahed, H. Hebhoub, L. Kherraf, and M. Belachia, "Effect of Cockele Shells on Mortars Performance in Extreme Conditions," Civ. Environ. Eng. Reports, vol. 29, no. 2, pp. 60-73, 2019, doi: 10.2478/ceer-2019-0017.

47. E. I. Yang, S. T. Yi, and Y. M. Leem, "Effect of oyster shell substituted for fine aggregate on concrete characteristics: Part I. Fundamental properties," Cem. Concr. Res., vol. 35, no. 11, pp. 2175-2182, 2005, doi: 10.1016/j.cemconres.2005.03.016.

48. F. Wheaton, "Review of oyster shell properties. Part II. Thermal properties," Aquac. Eng., vol. 37, no. 1, pp. 14-23, 2007, doi: 10.1016/j.aquaeng.2006.11.002.

49. H.-Y. Chen, L. G. LI, Z.-M. Lai, A. K.-H. Kwan, P.-M. Chen, and P.-L. NG, "Effects of Crushed Oyster Shell on Strength and Durability of Marine Concrete Containing Fly Ash and Blastfurnace Slag.," Mater. Sci., vol. 25, no. 1, 2019, doi: 10.5755/j01.ms.25.1.22437.

50. W. T. Kuo, H. Y. Wang, C. Y. Shu, and D. S. Su, "Engineering properties of controlled lowstrength materials containing waste oyster shells," Constr. Build. Mater., vol. 46, pp. 128- 
133, 2013, doi: 10.1016/j.conbuildmat.2013.04.020.

51. U. G. Eziefula, J. C. Ezeh, and B. I. Eziefula, "Properties of seashell aggregate concrete: A review," Constr. Build. Mater., vol. 192, no. March 2019, pp. 287-300, 2018, doi: 10.1016/j.conbuildmat.2018.10.096.

52. M. Azmi and M. Johari, "Cockle Shell Ash Replacement for Cement and Filler in Concrete," Malaysian J. Civ. Eng., vol. 25, no. 2, pp. 201-211, 2013, doi: 10.11113/mjce.v25n2.303.

53. A. P. Adewuyi, S. O. Franklin, and K. A. Ibrahim, "Utilization of mollusc shells for concrete production for sustainable environment," Int. J. Sci. Eng. Res., vol. 6, no. 9, pp. 201-208, 2015.

54. M. Olivia, A. A. Mifshella, and L. Darmayanti, "Mechanical properties of seashell concrete," Procedia Eng., vol. 125, pp. 760-764, 2015, doi: 10.1016/j.proeng.2015.11.127.

55. P. Lertwattanaruk, N. Makul, and C. Siripattarapravat, "Utilization of ground waste seashells in cement mortars for masonry and plastering," J. Environ. Manage., vol. 111, pp. 133-141, 2012, doi: 10.1016/j.jenvman.2012.06.032.

56. N. D. Binag, "Powdered Shell Wastes as Partial Substitute for Masonry Cement Mortar in Binder, Tiles and Bricks Production,” Int. J. Eng. Res. Technol., vol. 5, no. 7, pp. 70-77, 2016.

57. G. O. Bamigboye, A. T. Nworgu, A. O. Odetoyan, M. Kareem, D. O. Enabulele, and D. E. Bassey, "Sustainable use of seashells as binder in concrete production: Prospect and challenges," J. Build. Eng., vol. 34, no. April 2020, p. 101864, 2021, doi: 10.1016/j.jobe.2020.101864.

58. J. Burt, A. Bartholomew, A. Bauman, A. Saif, and P. F. Sale, "Coral recruitment and early benthic community development on several materials used in the construction of artificial reefs and breakwaters," J. Exp. Mar. Bio. Ecol., vol. 373, no. 1, pp. 72-78, 2009, doi: 10.1016/j.jembe.2009.03.009.

59. C. Varhen, S. Carrillo, and G. Ruiz, "Experimental investigation of Peruvian scallop used as fine aggregate in concrete," Constr. Build. Mater., vol. 136, pp. 533-540, 2017, doi: 10.1016/j.conbuildmat.2017.01.067.

60. G. Bamigboye, D. Enabulele, A. O. Odetoyan, M. A. Kareem, A. Nworgu, and D. Bassey, "Mechanical and durability assessment of concrete containing seashells: A review," Cogent Eng., vol. 8, no. 1, 2021, doi: 10.1080/23311916.2021.1883830.

61. S. Ha, J. W. Lee, S. H. Choi, S. H. Kim, K. Kim, and Y. Kim, "Calcination characteristics of oyster shells and their comparison with limestone from the perspective of waste recycling," $J$. Mater. Cycles Waste Manag., vol. 21, no. 5, pp. 1075-1084, 2019, doi: 10.1007/s10163-01900860-2.

62. Y. Zhang, D. Chen, Y. Liang, K. Qu, K. Lu, S. Chen, and M. Kong, "Study on engineering properties of foam concrete containing waste seashell," Constr. Build. Mater., vol. 260, p. 119896, 2020, doi: 10.1016/j.conbuildmat.2020.119896.

63. E. I. Yang, M. Y. Kim, H. G. Park, and S. T. Yi, "Effect of partial replacement of sand with dry oyster shell on the long-term performance of concrete," Constr. Build. Mater., vol. 24, no. 5, pp. 758-765, 2010, doi: 10.1016/j.conbuildmat.2009.10.032.

64. Y. J. N. Djobo, A. Elimbi, J. Dika Manga, and I. B. Djon Li Ndjock, "Partial replacement of volcanic ash by bauxite and calcined oyster shell in the synthesis of volcanic ash-based geopolymers," Constr. Build. Mater., vol. 113, pp. 673-681, 2016, doi: 10.1016/j.conbuildmat.2016.03.104.

65. S. Cheng, Z. Shui, R. Yu, T. Sun, and X. Zhang, "Multiple influences of internal curing and supplementary cementitious materials on the shrinkage and microstructure development of 
reefs aggregate concrete," Constr. Build. Mater., vol. 155, pp. 522-530, 2017, doi: 10.1016/j.conbuildmat.2017.08.037.

66. M. D. A. Thomas, R. D. Hooton, A. Scott, and H. Zibara, "The effect of supplementary cementitious materials on chloride binding in hardened cement paste," Cem. Concr. Res., vol. 42, no. 1, pp. 1-7, 2012, doi: 10.1016/j.cemconres.2011.01.001. 